\title{
The influence of the Chinese government's political ideology in the field of corporate environmental reporting
}

\author{
Hui Situ \\ School of Accounting, Information Systems and Supply Chain, RMIT University, \\ Melbourne, Australia \\ Carol Tilt \\ UniSA Business, University of South Australia, Adelaide, Australia, and \\ Pi-Shen Seet \\ School of Business and Law, Edith Cowan University, Joondalup, Australia
}

\begin{abstract}
Purpose - In a state capitalist country such as China, an important influence on company reporting is the government, which can influence company decision-making. The nature and impact of how the Chinese government uses its symbolic power to promote corporate environmental reporting (CER) have been understudied, and therefore, this paper aims to address this gap in the literature by investigating the various strategies the Chinese government uses to influence CER and how political ideology plays a key role.

Design/methodology/approach - This study uses discourse analysis to examine the annual reports and corporate social responsibility (CSR) reports from seven Chinese companies between 2007 and 2011. And the data analysis presented is informed by Bourdieu's conceptualisation of symbolic power.

Findings - The Chinese government, through exercising the symbolic power, manages to build consensus, so that the Chinese government's political ideology becomes the habitus which is deeply embedded in the companies' perception of practices. In China, the government dominates the field and owns the economic capital. In order to accumulate symbolic capital, companies must adhere to political ideology, which helps them maintain and improve their social position and ultimately reward them with more economic capital. The findings show that the CER provided by Chinese companies is a symbolic product of this process.

Originality/value - The paper provides contributions around the themes of symbolic power wielded by the government that influence not only state-owned enterprises (SOEs) but also firms in the private sector. This paper also provides an important contribution to understanding, in the context of a strong ideologically based political system (such as China), how political ideology influences companies' decision-making in the field of CER.
\end{abstract}

Keywords State capitalism, Symbolic power, Corporate environmental reporting, Ideology, China, Bourdieu Paper type Research paper

\section{Introduction}

The Chinese economy has grown rapidly since 1978 when the economic reforms in that country began. By 2008, the Chinese economy had become the second largest in the world in

(C) Hui Situ, Carol Tilt and Pi-Shen Seet. Published by Emerald Publishing Limited. This article is published under the Creative Commons Attribution (CC BY 4.0) licence. Anyone may reproduce, distribute, translate and create derivative works of this article (for both commercial and non-commercial purposes), subject to full attribution to the original publication and authors. The full terms of this licence may be seen at http://creativecommons.org/licences/by/4.0/legalcode

This research was supported by an Australian Government Research Training Program (RTP) Scholarship. The authors thank the editor and anonymous reviewers for their helpful comments on the paper.

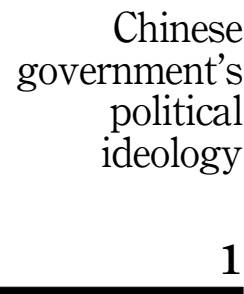

Received 2 September 2016 Revised 25 March 2019 12 June 2020

28 August 2020

Accepted 2 September 2020 
AAAJ

34,9

2

terms of gross domestic product (GDP) (World Bank, 2010). These economic reforms have been driven substantially by the Chinese central government, and recent scholars have noted the positive role of ideology in driving those reforms, notwithstanding that economists historically view ideology as "distorting ... knowledge, judgment and decision making" (Lieber, 2013, p. 344). With rapid economic growth, China has also experienced significant environmental degradation, and this has led to the Chinese government becoming increasingly involved in encouraging environmental reforms, similar to its pro-activeness in economic reform. In 2005, a new political ideology of building a "Harmonious Society" (of which the environment is a key element), was introduced by the then Chinese leader, Hu Jintao [1] and this has been quickly translated into being a key part of the nation's policies. Recent studies have found that, facing pressure, Chinese companies have accepted corporate environmental reporting (CER) as a management tool to communicate with their stakeholders (Gao, 2011; Situ and Tilt, 2012; Dong et al., 2014). However, there has been limited examination of the motivations behind the growth of CER in China.

Moreover, research in this area has traditionally focussed on companies in more developed economies, usually in the West, where there has been a longer history of environmental activism (such as: Magness, 2006; Shenkin and Coulson, 2007; Milne et al., 2009; Tilling and Tilt, 2010; Killian and O'Regan, 2016; Egan and Tweedie, 2018; Tadros and Magnan, 2019). But recently, there has been increasing interest in understanding reporting in emerging economies that have a significant impact on the environment (Situ and Tilt, 2018; Tilt, 2018; Finau, 2020; Arayssi et al., 2020), particularly as they experience growth and move towards a more (state) capitalist orientation (such as: Lauwo et al., 2016; Situ and Tilt, 2018). China is one example of such an economy and although it is now heading towards a market economy, as a one-party-led socialist country, China's political system, economy and culture are very different from other countries in that the government still dominates the economy. Its intervention is a strategic long-term policy choice, and markets function primarily as a tool that serves the national interest (The Economist, 2012). While there is a relatively good understanding of the direct nature of state influence, especially among state-owned enterprises (SOEs), there is a gap in our knowledge of the broader nature of that influence and how it manifests within organisations more generally. In particular, how the Chinese government exercises indirect (invisible) power, so that political ideology is integrated into CER decision-making, is not clear. Adopting a critical perspective, this paper focusses on understanding whether and how the Chinese government's political ideology shapes the values that underpin Chinese CER.

It has been argued that the pivotal role of ideology has been emphasised throughout the enactment of Chinese reform by the Chinese leaders (Lieber, 2013). However, the importance of political ideological influence on accounting practices and reporting in China is often overlooked (Yee, 2009). Recently, a small number of critical researchers have started to investigate this, and they have found that there is a close link between political ideology and the reform/development of accounting in China (Ezzamel et al., 2007; Yee, 2009; Xu et al., 2018). However, these studies have focussed on the political ideological influence on accounting regulations (Ezzamel et al., 2007), the accounting profession (Yee, 2009) and the accounting system (Xu et al., 2018), whereas research that investigates the problems of CER as a product of symbolic power is lacking. This study aims to narrow this gap by critically examining the discourse on political ideology within the practice of CER.

Increasingly, accounting is being recognised as a social practice that is shaped by and that shapes society (Ezzamel et al., 2007; Hafenbrädl and Waeger, 2017; Brown and Tregidga, 2017; Xu et al., 2018; Hummel and Hörisch, 2020; Quinche-Martín and Cabrera-Narváez, 2020). Along with the emergence of the new political ideology of a "Harmonious Society" in China, CER has become a new field of conflict between groups of different interests. Therefore, through the lens of Bourdieu's conceptualisation of symbolic power, this study explores how 
the Chinese government manifests its symbolic power in influencing companies' decisionmaking in the field of CER. This study uses critical discourse analysis (CDA) to examine seven major companies' annual/CSR reports in both Chinese and English as well as other forms of data such as media reports related to these firms to see how political ideology has been integrated into the discursive strategy of CER. It argues that, through exercising the symbolic power of regulator, shareholder and appointer, the Chinese government manages to build consensus among major Chinese companies, so that the political ideology is naturalised and becomes the habitus embedded in the companies. This process of turning political ideology into naturalised habitus is where the symbolic power is revealed. Through examining environmental reporting, this study aims to uncover the symbols within the discourse and reveal the symbolic power behind the process.

The study contributes to the interdisciplinary and critical accounting literature by integrating philosophy into accounting study, which provides a new angle to understand how state capitalism is manifesting itself in the rapidly changing Chinese economy. In so doing, it addresses a major gap identified in interdisciplinary accounting research (IAR) that the complexities and political understanding of "translation" have largely been ignored in IAR research (Kamala and Komori, 2018) by using the most relevant data sources for this type of research (Dumay and Guthrie, 2019).

The next section overviews the theoretical framework, the political structure in China and the symbolic role of the Chinese government. This is followed by the research method employed in this paper and then the findings. Finally, conclusions are drawn and implications for further research are outlined.

\section{Theory of symbolic power and structuralism in China}

\subsection{Bourdieu's theory of symbolic power}

Bourdieu's theory of symbolic power critically analyses how power is "mediated both by the cognitive and behavioural dispositions of individual agents and ... by relations of domination between social classes and the institutions of the modern state" (Cronin, 1996, p. 72). It is seen as powerful in revealing taken-for-granted power relationships (Bourdieu and Wacquant, 1993; Farjaudon and Morales, 2013; Stringfellow et al., 2015). The core concept of the theory of symbolic power consists of social space (field), habitus (disposition) and different types of capital. A social space is "a field of force through which the arbitrary is naturalised, and is located within the more general field of power" (Stringfellow et al., 2015, p. 88). In China, the general field of power refers to the state capitalism structure, where the Chinese government uses three types of powers and controls to inculcate its political ideology throughout the country.

According to Bourdieu and Wacquant (1993), social space denotes the symbolic structure/ system. It is constructed in a way that agents are distributed in different positions of the social space depending on the capital they occupy. Generally, agents who have common capital have similar interests/stakes and, therefore, the closer these agents are. The agents who occupy the higher positions in the hierarchies of the space through building of consensus are able to impose their interests on others (Bourdieu, 1989). For example, Farjaudon and Morales (2013) examine how the financial value of branding has taken over the market value of branding in an organisation. They argue that branding is traditionally perceived as a marketing issue. However, in their study, the company introduced a new managerial accounting device: the financial valuation of brands, which shifted the definition to a more financial focus. This process builds consensus within the organisation that is focussed on the financial value of branding (which represents the shareholders' interest). This therefore allows the marketing manager to focus on financial aspects when making decisions. Ultimately, through building alignment, the shareholders' stake in modern corporations has been successfully promoted as the legitimate dominant interest (Farjaudon and Morales, 2013). The strategy to build and 
legitimise consensus is to deny positional conflicts, so that their interests become the universal interest. At the same time, the process of building consensus creates the feeling of collegiality, which enables other groups to practice pursuing the dominant group's interest in the belief of pursuing their own interest. Habitus is the key to this process.

While social space refers to the social reality, habitus is the perception of this reality which is determined by the agents' position in objective social space (Bourdieu, 1989). According to Stringfellow et al. (2015), habitus is a set of perceptions and thoughts that reflect the social structure and the representations of situations of action. In other words, habitus is a sense of the social space (of the agents themselves and others), which "resides in the agents as an embedded structure through the learning process" (Sylvia et al., 2018, p. 371). Therefore, when one constructs his/her perspective of the world, it is constrained by his/her social position. However, habitus is not only a system of perception of practices, but also "a system of schemes of production of practices" (Bourdieu, 1989, p. 19). Due to the different positions occupied by the agents, practices produced by habitus can be classified, and objectively differentiated and become the symbol of the agents' position in the social space (Bourdieu and Wacquant, 1993; Bourdieu, 1989). The process to distinguish and differentiate one group from others in a specific social space is the process used to produce symbolic power of one group over the others. The group that owns more symbolic capital occupies the higher-level social position and becomes the dominant group. This differentiation creates asymmetric power between groups. This symbolic power enables dominant groups to define the classification and set up the rules of the game, within the field and ultimately legitimise their interest as the common interest (Bourdieu and Wacquant, 1993; Bourdieu and Nice, 1990). When making decisions, companies are constrained by their social position. The Chinese government dominates the social space and can use its symbolic power to make its political ideology the consensus among companies and ultimately to become their habitus.

Capital is also important in creating power, as it determines who has the opportunity to be the powerful actor in the field. Capital in Bourdieu's theory is "the power in valued resources" (Swartz, 2007, p. 107). Capital not only refers to economic capital, but also cultural capital, political capital or other types of symbolic capital. Capital can be created, accumulated, exchanged and consumed. According to Bourdieu (1989), in a modern society, there are different fields, each with its own stakes, and therefore each has its own symbolic capital. Given the relation between symbolic capital and power, agents need to accumulate symbolic capital to gain or maintain their power. In order to accumulate symbolic capital, the nondominant groups are often willing to practice and act in ways that follow the dominant group's logic without the need to resort to violence to force them to obey the rules. In other words, symbolic power is recognised, rather than forced. In order to accumulate symbolic capital, the Chinese companies are willing to disclose environmental information, even though the government does not mandate them to do so.

Over the years, Bourdieu's theory has been increasingly applied to accounting research (e.g. Celerier and Cuenca Botey, 2015; McPhail et al., 2010; Brown and Dillard, 2014; Cooper and Coulson, 2014; Killian and O'Regan, 2016; Ferguson et al., 2016; Fukofuka and Jacobs, 2018; Egan and Tweedie, 2018; Semeen and Islam, 2020). However, most of these studies have focussed on accounting practices in more developed economies, and research in the context of emerging economies has been lacking. Given the difference in culture, the level of economic development and the political structure, research in accounting in emerging economies through a Bourdieu lens could develop a better understanding of accounting practices in the contexts in which they operate (Malsch et al., 2011). Therefore, this paper is an early attempt to fill this gap.

\subsection{The symbolic role of the Chinese government}

Bourdieu's theory is widely used when exploring hidden power relationships, especially those relationships that are shaped by, and will shape, the disposition of the actors in the 
social structure. Language is viewed as the media of power. According to Bourdieu (1991, p. 64), "different agents' linguistic strategies are strictly dependent on their positions in the structure of the distribution of linguistic capital". The dominant group, in order to impose its language as the legitimate language, has to unify the linguistic market. It can be seen that the integration into a single linguistic community (i.e. a "group of people who use the same system of linguistic signs") is a product of the political domination (Bourdieu, 1991). By examining the discourse on political ideology within the Chinese government's policies, media and CERs (the approach to this will be further elaborated on in Section 3.2), our research investigates how the Chinese government manifests its symbolic powers in field of CER among both SOEs and non-SOEs. In this paper, an argument is posited that in the field of $\mathrm{CER}$, the Chinese government exercises three forms of symbolic power to build consensus among Chinese companies. Through the quest for consensus, political ideology becomes the habitus which is deeply embedded in the companies' perception of CER practices. CER, as a product of symbolic power, helps companies accumulate symbolic capital (although potentially mediated by global pressures) and ultimately maintain/gain domination of the field. The domination of the field, in turn, helps companies gain economic capital. This process is represented by the conceptual framework presented in Figure 1.

As discussed earlier, social space determines the agents' points of view of the world. In order to understand the symbolic power processes in the field of CER, it is important to review the logic of domination in China as a state capitalist country (symbolic structure).

China's political system can be described as "state capitalism", which is "a form of bureaucratically engineered capitalism particular to each government that practices it. It's a system in which the state dominates markets primarily for political gain" (Bremmer, 2010, p. 250). State capitalism tries to meld the power of the state with the power of capitalism so instead of eliminating markets, governments try to harness them for their own purposes (The Economist, 2012). It depends on the government to pick winners and promote economic growth. It also uses capitalist tools such as listing SOEs on the stock market and embracing

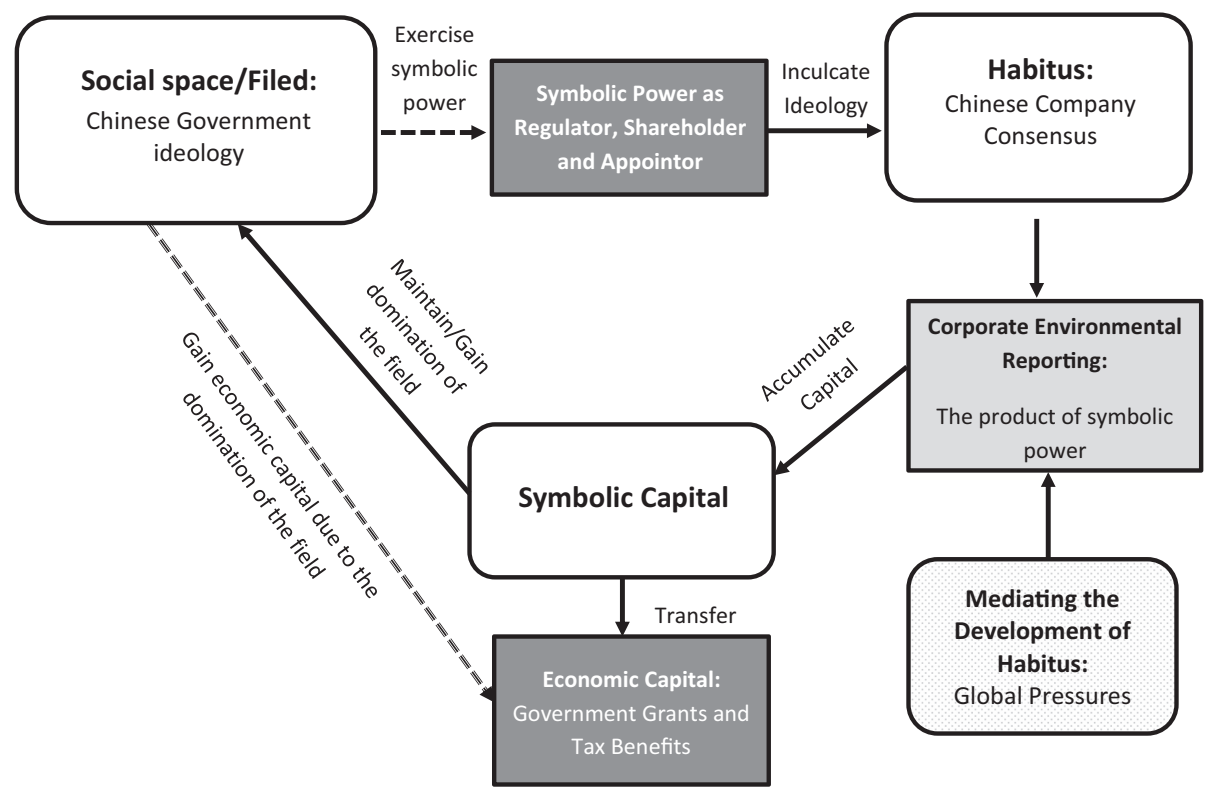

\section{Chinese government's political ideology}

Figure 1.

Conceptual framework based on Bourdieu's theory of symbolic power 
AAAJ

34,9

6

globalisation (The Economist, 2012). Although a state capitalist economy is different from a command economy where the government directly exerts day-to-day control, the government still has considerable direct influence over the economy and companies' strategy (Bremmer, 2010). To manage state capitalism, political leaders use a variety of tools (Bremmer, 2010). Chinese state capitalism is unique in a way that it inculcates its political ideology through three symbolic powers to sustain asymmetric relations of power and domination. They are (1) the exercise of the power and control as a regulator to encourage CER, (2) the exercise of power and control as the dominant shareholder and (3) the ability to appoint key positions in major firms.

Symbolic power as regulator. As discussed earlier, a "Harmonious Society" (with the environment as a key element) was introduced as the nation's priority. In response, the State Environmental Protection Administration (EPA) put into effect a "green securities" plan aimed at making it harder for polluters to raise capital and encouraging listed companies to disclose more information about their environmental records (Situ et al., 2013). In response to the plan, a series of guidelines for companies on disclosing social and environmental information was issued from 2006 onwards. This plan was further strengthened when in 2008, the Measures for the Disclosure of Environmental Information (MDEI), which encourages Chinese companies to disclose environmental information, was enacted. This symbolised the Chinese government's acceptance of environmental disclosure as a new environmental governance mechanism.

Symbolic power as shareholder. The Communist party (referred to as "the party" after this) exerts shareholder power over SOEs through the State-Owned Assets Supervision and Administration Commission (SASAC). Chinese SOEs play an instrumental role in society (Du and Wang, 2013), and the role of SOEs is more than just business. In China, SOEs make up $80 \%$ of the stock market's capitalisation value (The Economist, 2012) and are seen to be the backbone of the Chinese economy. Among the 57 Chinese firms on the list of Global Fortune 500 companies in 2011, almost all of them were SOEs (Li et al., 2012). Among SOEs, the largest shareholder is the Chinese government, and therefore it can use SOEs as tools to achieve its political and social goals. As protecting the environment has become a major part of the political leaders' guiding ideology and the nation's prior policy, as expected, SOEs have been encouraged to be pacesetters in CER.

Symbolic power as appointor. The party exercises power over the appointment of the senior leadership of all SOEs through the party's Organisation Department, which determines all senior executive positions in SOEs (Landry, 2008). A study of the 130 leaders of SOEs found that more than $50 \%$ of SOE leaders serve as both general manager and party secretary/deputy party secretary and that a further $10 \%$ play threefold concurrent roles as general manager, chairman of the board of directors and party secretary/deputy party secretary (Li, 2011). This has resulted in control over the leaders of China's SOEs in that they are "cadres first and company men second. They care more about pleasing their party bosses than about the global market" (The Economist, 2012, p. 6). In essence, the exercise of power in this form is in line with what Lukes (1974) stated was a means of ensuring compliance and overcoming opposition. In addition, the party has cells in most large firms private and state-owned - with their own offices and files on employees. These cells hold meetings that influence business decisions made at formal board meetings and sometimes even override them. Through these means, the Chinese government wields power over Chinese organisations, as it implements the ideology of building up a harmonious society.

As summarised in Figure 1 and the review of literature, this paper argues that CER is not a natural entity, but a symbolic product resulting from the interaction of the power of the Chinese government and different companies in the field. In particular, this paper looks at how the Chinese government's political ideology and symbolic power influence corporate environmental reports. Therefore, Bourdieu's theory is applied in this study to examine the indirect exercise of power by the Chinese government on CER. 


\section{Research design}

\subsection{Empirical data}

It is argued that "depending on the funding, time and other constraints, smaller studies are, of course, useful and legitimate. [. . . one can certainly conduct only a few case studies and must restrict the range of the data collection (to very few genres)" (Wodak and Meyer, 2009, p. 96). Parker and Northcott (2016) also note that sample size is not the focus of a qualitative study. Therefore, this study employs discourse analysis of a small sample of Chinese companies' annual/CSR reports, chosen from the Shanghai Stock Exchange (SSE) 180.

According to Wodak and Meyer (2009), a range of empirical data could be collected, considering the following criteria: (1) specific political units, (2) specific periods of time relating to important discursive events, (3) specific social and especially political and scientific actors, (4) specific discourses, (5) specific fields of political action and specific policy fields and (6) specific semiotic media and genres. Moreover, Situ et al. (2015) examined SSE 180 companies' annual reports and stand-alone CSR reports for the period 2007-2011 and found some preliminary evidence that the Chinese government has influenced Chinese CER. Following their descriptive analysis, this study, using the same sampling frame to enable more in-depth results, seeks to consider how the State influences Chinese CER by using its symbolic powers.

As the study is interested in both the influence of the Chinese government on the discourse and any potential influence of the West, the sampling frame was divided into four groups depending on whether the companies are state-owned (SOE) and whether they are listed on a foreign stock exchange (dual-listed). The four groups comprise: SOE and dual-listed; nonSOE and dual-listed; SOE and non-dual-listed; and non-SOE and non-dual-listed. From each of these four groups, two companies were selected for analysis: the company with the highest level of CER disclosure and that with the median level of disclosure. Because CER is still in its early stages in China, the volume of environmental reporting by Chinese companies is relatively small so those companies with the highest level of disclosure provided enough data to allow a comprehensive analysis. The company with the median level was selected to represent the disclosure made on average. Both the selected companies' annual reports and CSR reports produced during each of the years from 2007 to 2011 (inclusive) are examined. The sample therefore comprised of seven companies, which resulted in 70 documents (seven companies' annual reports and CSR reports over five years). A summary of the selected companies is shown in Table 1.

To understand symbolic power better, different sources of documents, Chinese governments' policies (such as MDEI, SASAC's Agenda and previous research papers about the Chinese government's work papers) and the mainstream newspapers (such as the China Daily, the Global Times) were also examined to see the relationship between texts, in

\begin{tabular}{llll}
\hline SSE stock code & Company name & Ownership & Industry \\
\hline 601919 & China COSCO & Dual-listed and SOE & Transport \\
601600 & China Aluminum & Dual-listed and SOE & Manufacturer \\
600432 & JiEn Nickel Industry & Non-dual-listed and SOE & Manufacturer \\
600019 & Baosteel & Non-dual-listed and SOE & Manufacturer \\
$* 600016$ & Minsheng Bank & Dual-listed and Non-SOE & Bank \\
601166 & Industrial Bank & Non-dual-listed and Non-SOE & Bank \\
600660 & Fuyao Glass Industry & Non-dual-listed and Non-SOE & Manufacturer
\end{tabular}

Note(s): *There is only one company in the group of Dual-listed and Non-SOE. And, therefore, only one company has been selected to the sample

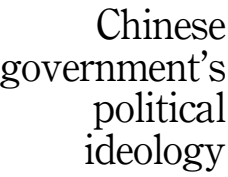

7 
AAAJ 34,9

8 order to reveal evidence of the symbolic power during the process of turning the Chinese government's political ideology into habitus among Chinese companies.

\subsection{Data analysis approach}

CDA is interested in analysing opaque structural relationships of dominance, discrimination, power and control as manifested in language (Wodak and Meyer, 2009). It considers language as a device which contributes to the (re)shaping and maintenance of social relationships (Tregidga and Milne, 2006; Van Dijk, 2009). This is consistent with the view that CER is a tool for corporations to develop, maintain and defend their relationships with society (Deegan, 2009). Discourse is defined as "a system of texts that bring an object into being" (Hardy and Phillips, 1999, p. 2). Analysis of discourse is important since the relationship between text and context is inseparable, and context is extremely important in the construction of text (Tregidga and Milne, 2006). For this study in particular, historical context is important. By analysing the text, "we seek to acknowledge its constitutive nature and transformative potential" (Tregidga and Milne, 2006, p. 224).

Wodak and Meyer (2009) argue that objective social situations that are determined by social structures (such as gender, class or ethnicity) cannot sufficiently demonstrate the influence of social context on language variation; it is the subjective definitions of social situations that influence discourse. These subjective definitions are determined by the socialpsychological (cognitive) contexts of the relevant actors. Ideology is one of these socialpsychological factors as it is the mental reflection of the world shared by a group in a certain period (Van Dijk, 2009; Wodak and Meyer, 2009). It is important to include this context within the analytical process. CDA offers insight into the interplay between social structures and individual actors and offers a way to re-conceptualise subjectivity and agency in more cognitivist terms (Glynos et al., 2009, p. 18). This view is consistent with Bourdieu's view that it is necessary to understand the symbolic system as structured structures and structuring structures. Therefore, $\mathrm{CDA}$ is viewed as appropriate for this study, which attempts to analyse the discourse in CER to identify ideology within the Chinese social and political context.

The data analysis presented is informed by Bourdieu's conceptualisation of symbolic power. In the following section, we use the three powers outlined in Section 2 to frame the links among the discourse of CER and symbolic power processes. A four-step analysis is employed in this study.

Step 1: Identify the specific field of a specific discourse. According to Wodak and Meyer (2009), discourse is a cluster of context-dependent semiotic practices that are situated within specific fields of social action. In China, the political ideological themes change along with the change of leadership. The Chinese government and its agents' policies and guidelines during 2007-2011 are examined, in order to find out what new political ideology has emerged under $\mathrm{Hu}$ Jintao's leadership. We argue that CER is the new field that is promoted by the Chinese government to facilitate the new political ideology. In applying the first step, the following question is developed to guide the analysis:

(1) What is the new field and political ideology that emerged under Hu Jintao's leadership?

Step 2: Examine linguistic means. The approach for examining linguistic means is to perform a descriptive analysis of the text. In this study, CER as a discourse that unfolds across a number of inter-related social contexts is examined. A set of subtopics of CER discourse is developed by using the major CSR guidelines, GRI, SSE guideline [2] and MDEI, in China. The three guidelines overlap with each other. However, while GRI has more comprehensive indicators, which include the indicators of biodiversity and rehabilitation, the MDEI and SSE guidelines focus more on energy-saving and emissions reduction. Therefore, this study develops five categories of themes (General Statement, Management Approach, Energy 
Saving and Pollutant Emission, Compliance Biodiversity and Rehabilitation). We use NVivo software for coding. First, a text search is performed by using the key words: 环境 (Environment), 生态(Ecology), 自然(Nature), 绿色(Green), 污(Pollution), 废(Waste), 减 排(Emission Reduction), 节能(Energy Saving) and 环保(Environmental Protection). Then, sentences near the key words are read; if the sentences are related to environmental information of the themes described earlier, the full sentences are collated and categorised into different themes. We argue that the Chinese government, as a regulator, exercises its symbolic power to define environmental protection. By examining which topics have been disclosed, and which have not, the relationship between the government and Chinese CER is explored. To guide the examination of the linguistic means, the following questions are used:

$\begin{array}{r}\text { Chinese } \\ \text { government's } \\ \text { political } \\ \text { ideology } \\ \mathbf{9} \\ \hline\end{array}$

(1) What does "environment" mean when referred to by the companies?

(2) Is there any inter-discursive relationship between the CER and the government's policies and guidelines?

Step 3: Investigate discursive strategies. To investigate discursive strategies is to find out what is the particular social, political, psychological or linguistic goal the companies want to achieve. When investigating the discursive strategies, the analysis is especially interested in revealing the implicit or indirect meaning of the discourse, since such meanings are related to underlying beliefs. As argued by Van Dijk (2009), discourse is the mental representation of the social context, so in order to find out the complex relationship between discourse and context, the implication of the discourse should be analysed. In this step, we look at the Chinese government, as both a shareholder and an appointor, and how it exercises symbolic power to build consensus among companies and thus successfully inculcate environmental protection as a habitus within Chinese companies. Selected companies' annual reports and CSR reports are fully read. Words such as "actively", "positively", "strengthen", "attach great importance to", "set high priority to", "strive" and "resolutely implement" are highlighted to examine the companies' attitude when discussing environmental protection. In order to explore the Chinese government's ideological influence in the discourse, ideological words such as "scientific development", "harmony", "harmonious society" are also highlighted. Three questions are established to guide the investigation of the discursive strategies in this study:

(1) Do the companies communicate positively or negatively about the environment?

(2) Are there any particular perspectives taken by the companies, in terms of the environment?

(3) What arguments are employed in the discourse to support their claims?

Step 4: Examine the specific, context-dependent linguistic realisations. CDA links detailed discourse analysis with broader social practices analysis. It reflects social construction, but also shapes individuals' interaction with society. Therefore, in this step, we explore how the discourse is reconstructed and deconstructed between different contexts. First, we examine the process of how symbolic capital has the potential to turn into the economic capital that is essential for the Chinese companies' survival. Then we discuss the struggle in constructing CER in China, where Western influences begin to have a moderating effect on the strength of the government's political ideology.

\section{The Chinese government's exercise of symbolic power on CER}

Previous studies (Gao, 2011; Situ and Tilt, 2012; Situ et al., 2013; Dong et al., 2014) have consistently found that being an SOE tends to having a higher level of CER. Fundamentally, 
AAAJ

34,9

the Chinese leadership seeks to continuously restructure and improve central control over economic decision-making (McNally et al., 2013) with SOEs playing a key role. Since protecting the environment is a major part of the guiding ideology and the nation's policy, SOEs are eager to provide CER. However, in this study, both SOEs and non-SOEs report on the government's policies to a similar extent suggesting that the Chinese government's influence on Chinese CER is more widespread. This section discusses the findings in relation to symbolic power, including discussion of the government's influence via three main powers as conceptualised earlier in the paper.

\subsection{The new field and habitus that emerged under Hu Jintao's leadership}

Bourdieu (2015, pp. 213-214) notes that the "state is a theoretical unifier, a theorist. It carries out a unification of theory; it takes a central and superior viewpoint, that of totalization". This is especially so in China. China is a highly centralised country; all power is technically held by the central government, and the local governments are the executive agencies. In particular, the key political ideas of Chinese leaders are highly regarded by the Chinese people. For a long time, "the government has made it an important task to propagate the political ideologies of the Communist leaders and to inform the public about government decisions and policies, with the aim of 'inspiring' and 'directing' the Chinese people in the country's social and economic construction" (Yee, 2009, p. 79). In this way, the Chinese people have been taught that the government always stands for the public, that the interest of the country is the same as the interest of the public, so there is no conflict with them and the government has a right to rule. Moreover, historically, "the Chinese ruling class often placed importance in the propagation of its political ideologies, so much so that these ideologies become part of the culture of the Chinese people" (Yee, 2009, p. 80), that is, the political ideology reflects the prevailing Chinese leader's direction.

The prevailing political ideological themes are dynamic. Along with economic reforms, new political ideological themes have been developed to respond to the changing social stratification. Before the recent economic reforms, China experienced a long period of economic disorder. In the late 1970s, food supplies and production had become so deficient that the whole country was in poverty. So, in Presidents Deng Xiaoping's and Jiang Zemin's tenures, economic growth was conceived as a choice without alternatives. The signature ideology of building "a socialist market economy with specific Chinese characteristics" (Zhang, 2012, p. 25) easily gained consent and acceptance as being in the common interest of the whole country.

These reforms have boosted the Chinese economy and improved the people's living standards; however, the blind pursuit of growth in GDP has also brought with it a series of environmental problems (Zheng, 2010). The combined economic and human health impact cost of outdoor air and water pollution for China's economy was around US $\$ 100 \mathrm{bn}$ p.a., which was about $5.8 \%$ of the country's GDP (World Bank and State Environmental Protection Administration, 2007). This has resulted in increasing criticism and expectations, both internally and externally, that China should respond. Facing these pressures, Hu's government realised the old ideology needed to be shifted to a new one to gain consensus. Therefore, a new political commitment of building up a "Harmonious Society" was introduced with the environment as a key element and has become a new leading ideology.

To construct this new morality and gain consensus, a range of market-based instruments, charges and incentives were developed as tools to promote environmental protection. A pollutant charge system was introduced. Then new resource tax standards for mining products, tariffs on energy-intensive products and taxation incentive policies for low pollution and low energy consumption were implemented one after another (van den Burg, 2008). By 2009, China had become the world's largest clean energy investor, reaching 
US $\$ 34 \mathrm{bn}$, almost double the United States' investment of US\$18bn (Pew Charitable Trust, 2010).

In recent times, several scholars (such as Nelson, 2008; Xue et al., 2007; Zhang et al., 2007) have argued that to improve the environmental situation in China, something must be done beyond the government. Specifically, the business sector, as the biggest polluter of the Chinese environment, should play its role in improving the environmental situation, independent of pollution enforcement by the government. Encouraging Chinese companies to disclose more environmental information, thus making their activities more transparent, is likely to be a useful approach. This approach would take advantage of the influence that supply chain and community pressures have on Chinese companies, in addition to the influence of regulatory pressures on environmental performance, and may help to reduce the strain on environmental enforcement agencies, ultimately improving the environmental situation (Nelson, 2008). As such, CER has been promoted by the Chinese government as a tool to facilitate a harmonious society, and this has led to a dramatic rise in CER in China.

According to Situ et al. (2015), the trend in environmental disclosure by Chinese companies is increasing, and it reached a peak of $85 \%$ in 2008 , from $52 \%$ in 2007 . It is evident that, under $\mathrm{Hu}$ Jintao's leadership, CER became a new field within the more general field of power (state capitalism) in China. As discussed earlier, under state capitalism, the Chinese government exercises symbolic power by using three powers and controls to inculcate its political ideology throughout the country.

\subsection{The Chinese government's exercise of symbolic power as regulator}

Under the notion of symbolic power, symbolic struggle refers to the struggle of changing categories of perception and schemes of interpretation. "Changing positions of power relate to strategies to enforce 'authoritative definitions' of contested concepts" (Everett, 2003 cited in Farjaudon and Morales, 2013, p. 156). Therefore, in the field of CER, the Chinese government needs to "create and specify meaningful categories and enforce their own logic as consensual and universal, such that they monopolise access to legitimate instruments of expression" (Farjaudon and Morales, 2013, p. 156). Moreover, dominant agents seek to impose legitimacy through symbolic products (such as discourse). One of the most important ways the modern nation can gain and reinforce their monopoly of power is to develop "the institution of a single national language through the codification of grammar and norms of correct usage" (Cronin, 1996, p. 71).

In China, traditionally "the 'correctness of language' has always been considered a source of moral authority, official legitimacy and political stability...The political language has been vested with an intrinsic instrumental value: its control represents the most suitable and effective way first to codify, and then widely convey, the orthodox state ideology" (Marinellin, 2012, p. 26). Our research finds evidence that this type of process is also reflected in Chinese CER. As the harmonious society is the "re-contextualized discourse in response to the emergent issues in the changing social stratification order" (Zhang, 2012, p. 33), it has become the meta-discursive ideology throughout China and significantly impacts Chinese companies' perceptions. As a result, Chinese companies have quickly adopted environmental protection into their CER.

According to the GRI guidelines (G3.1),

[t]he environmental dimension of sustainability concerns an organisation's impacts on living and non-living natural systems, including ecosystems, land, air, and water. Environmental Indicators cover performance related to inputs (e.g. material, energy, water) and outputs (e.g. emissions, effluents, waste). In addition, they cover performance related to biodiversity, environmental compliance, and other relevant information such as environmental expenditure and the impacts of products and services. 
AAAJ 34,9

\section{2}

However, the Chinese government emphasises energy saving and emission reduction in their national policy. As stated in Article 19 of the MDEI:

Enterprises are encouraged by the State to voluntarily disclose the following enterprise environmental information:

(1) Their environmental protection guidelines, annual environmental protection objectives and achievements;

(2) Their total annual resource consumption;

(3) Information on their environmental protection investment and environmental technology development;

(4) Type, volume and content of pollutants discharged by them and where the pollutants are discharged into;

(5) Information on the construction and operation of their environmental protection facilities;

(6) Information on the handling and disposal of waste generated from their production, information on recycling and comprehensive use of waste products;

(7) Voluntary agreements entered into with environmental protection departments for environment improvement behaviour;

(8) Information on their performance of social responsibilities; and

(9) Other environmental information voluntarily disclosed by them.

It can be seen that energy saving and emission reduction are specifically emphasised in three out of nine clauses. Since the enactment of the MDEI by the MEP, different departments, agencies and industrial associations have issued a growing number of requirements. However, all of them mirror the MDEI. For example, the SSE guideline is a reproduction of the MDEI, with the same nine clauses as shown earlier. To respond to the MDEI, the SASAC also issued the Guidelines to the State-owned Enterprises Directly under the Central Government (referred to as CSOE's Guideline hereafter), in which clause 11 states:

Strengthening resource conservation and environment protection. The large State-own enterprises should take their responsibilities and lead in energy saving and emission reduction. So, the enterprises have to upgrade their technology and equipment, and engage in the recycling economy, so as to develop energy-conserving products and improve resource utilisation efficiency. What is more, they should invest more to environment protection, rationalise production procedures, try to decrease the pollutant emission with a target lower energy consumption and less pollution but higher production efficiency and output.

This definition of environmental protection has also been spread widely by the Chinese mainstream media. For example, China Daily (2007) reports (with the title: New law to promote energy conservation) that:

BEIJING - Under heavy pressure to harness rampant energy consumption, China's top legislature on Wednesday began deliberating a draft amendment to the law that suggests work carried out by local government officials in energy conservation should be integrated into the assessment of their political performance.

On 25 Nov 2010, China Daily reported that "China to get tougher in energy saving, emission reduction" and stated that "China will resort to more legal, technical and fiscal measures for greater progress in energy saving and emission reduction over the next 5 yrs". 
In another mainstream media outlet, the Global Times (2012) also reported that China promotes the use of energy-saving internal combustion engines. At the end of the report, it emphasised that:

The latest move came amid China's growing emphasis on a cleaner and healthier growth model after years of rapid development have taken heavy tolls on the country's resources and environment.

By the end of 2015, China will lower its energy consumption per unit of GDP by 16 percent from 2010 and lower its carbon dioxide emissions per unit of GDP by 17 percent, according to the country's 12 th Five-year Plan (2011-2015).

Furthermore, Qian and Tian (2014), who examined the Chinese government's work reports from 1999 to 2008, found that from 2004, energy saving and emission reduction were the most frequent keywords that appeared. They note that the choice of keywords reflects new topics and changes in the Government Working Papers, which, as a new discourse, brings about social change through the effect of symbolic power on other social agents. By defining what is environmental protection, the Chinese government separates what is important from what is not.

Although the GRI defines environmental sustainability broadly in terms of environmental impact, in the reports from our sample companies, a much narrower definition is adopted in China with energy saving and emission reduction emerging as the main themes used by companies to show their responsibilities to the environment. Environmental protection is limited to resource conservation and emission reduction. For example, in China Aluminum's 2007 annual report, the title of the environmental section is "Developing a recycle economy, the effect of energy saving and emission reduction is remarkable", and in its 2008 annual report, the section title is "Further strengthening energy saving and emissions reduction". Its 2008 CSR report explicitly states that:

[t]he focal point of the group's social responsibilities are focusing on energy saving and emission reduction, attention and strictly controlling the environmental impact of business operations, strengthening resources recycling, and building up a resource-conserving company.

This is not unique to China Aluminum, and most of the sample companies provide evidence of their energy-saving and emission reduction activities to show how they achieve environmentally friendly operations. As stated by China COSCO Holding Co. Ltd. in its 2011 CSR report:

It continued to insist on the green development concepts, deepened the energy-conservation and emission reduction measures, performed its corporate citizenship responsibilities and tried to construct a resource-conservative and environment-friendly enterprise.

Even the banks focus on how they direct money to projects that invest in technology and equipment that facilitate energy saving and emission reduction and research on clean energy. In Minsheng Bank's 2009 annual report, it made a commitment to green finance and stated that:

The company manages green finance rigorously, supports energy saving and emission reduction, reduces the effect on the environment from its operation, positively responds to climate change, strives to build a green bank.

Evidently, energy saving and emission reduction are at the centre of Chinese companies' understanding of environmental protection. Most of the Chinese companies appear to view environmental protection as a response to the Chinese government's call to be a green business, and they believe they have the responsibility of putting the government's words into practice. Thus, this provides clear evidence of the dominant agent accumulating symbolic capital.

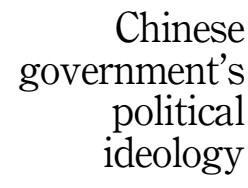


AAAJ 34,9

14

The Chinese government, by defining the meaning of environmental protection, distinguishes what is important and what is not. As such, energy saving and emission reduction have become the consensus in the field of Chinese CER. Even more so, energy saving and emission reduction have become the correct language to be used to show that the companies' interests align with the government's interest. As discussed in Section 2, the narrower the gap between actors and dominant groups, the more powerful the actors are and the more they accumulate symbolic capital and therefore gain symbolic power. As a state capitalist country, the Chinese government wields significant power and is depended upon to choose industry winners (Bremmer, 2010). Therefore, to narrow the gap from the government and partake in the power of the government, companies (both SOE and non-SOE) consciously and/or unconsciously follow the government and see energy saving and emission reduction as the main issues of environmental protection. Implicitly, this is evidence of the notion of symbolic power that shows that the government uses its regulator power and control to create and reinforce the habitus of Chines companies, which influences their decision-making about what is important information to be disclosed.

\subsection{The Chinese government's exercise of symbolic power as shareholder}

Under the notion of symbolic power, it is argued that the social identities of the discourse producer define its communication role and thus affect what it chooses to say or not say (Wodak and Meyer, 2009). As noted earlier, in a state capitalist country, SOEs play a key role in implementing the government's policies (Du and Wang, 2013; Zhao, 2012). The Chinese SOEs' shares are majority owned and controlled by the SASAC (as shown in Table 2), which is a department of the Chinese government. Such that, SOEs are deeply embedded in the Chinese government's bureaucratic structure. Therefore, it is not surprising to see the Chinese government promoting its interest as the companies' interest.

The CSOE guidelines promote the Chinese leader Hu Jintao's political ideology and propose CSOEs to "comprehensively implement the spirit of the 17th Communist Party of China (CPC) National Congress and the Scientific Outlook on Development, and give the impetus to stateowned enterprises directly under the central government (referred to as CSOEs hereafter) to

Table 2.

Background of sample companies

\begin{tabular}{|c|c|c|c|c|c|}
\hline $\begin{array}{l}\text { Company } \\
\text { name }\end{array}$ & Ownership & $\begin{array}{l}\text { On GRI } \\
\text { register }\end{array}$ & $\begin{array}{l}\text { Received } \\
\text { government } \\
\text { grant }\end{array}$ & $\begin{array}{l}\mathrm{CPC} \text { committee } \\
\text { within management } \\
\text { system }\end{array}$ & $\begin{array}{l}\text { Government } \\
\text { officer(s) in } \\
\text { management board }\end{array}$ \\
\hline $\begin{array}{l}\text { China } \\
\text { COSCO }\end{array}$ & $\begin{array}{l}\text { Dual-listed } \\
\text { and SOE }\end{array}$ & $\mathrm{Y}$ & $\mathrm{Y}$ & $\mathrm{Y}$ & $\mathrm{Y}$ \\
\hline $\begin{array}{l}\text { China } \\
\text { Aluminum }\end{array}$ & $\begin{array}{l}\text { Dual-listed } \\
\text { and SOE }\end{array}$ & $\mathrm{Y}$ & $\mathrm{Y}$ & $\mathrm{Y}$ & $\mathrm{Y}$ \\
\hline $\begin{array}{l}\text { Ji'En Nickel } \\
\text { Industry }\end{array}$ & $\begin{array}{l}\text { Non-dual- } \\
\text { listed and SOE }\end{array}$ & $\mathrm{N}$ & $\mathrm{Y}$ & $\mathrm{Y}$ & $\mathrm{Y}$ \\
\hline Baosteel & $\begin{array}{l}\text { Non-dual- } \\
\text { listed and SOE }\end{array}$ & $\mathrm{Y}$ & $\mathrm{Y}$ & $\mathrm{Y}$ & $\mathrm{Y}$ \\
\hline $\begin{array}{l}\text { Minsheng } \\
\text { Bank }\end{array}$ & $\begin{array}{l}\text { Dual-listed } \\
\text { and Non-SOE }\end{array}$ & $\mathrm{N}$ & $\mathrm{N}$ & $\mathrm{Y}$ & $\mathrm{Y}$ \\
\hline $\begin{array}{l}\text { Industrial } \\
\text { Bank }\end{array}$ & $\begin{array}{l}\text { Non-dual- } \\
\text { listed and Non- } \\
\text { SOE }\end{array}$ & $\mathrm{Y}$ & $\mathrm{Y}$ & $\mathrm{Y}$ & $\mathrm{Y}$ \\
\hline $\begin{array}{l}\text { Fuyao Glass } \\
\text { Industry }\end{array}$ & $\begin{array}{l}\text { Non-dual- } \\
\text { listed and Non- } \\
\text { SOE }\end{array}$ & $\mathrm{N}$ & $\mathrm{Y}$ & $\mathrm{Y}$ & $\mathrm{Y}$ \\
\hline
\end{tabular}


earnestly fulfil corporate social responsibilities (CSR), so as to realize coordinated and sustainable development of enterprises, society and environment in all respects." In Article 1, it highlights that the four important reasons for fulfilling CSR by the CSOEs as:

(1) A practical action taken by the CSOEs to apply the Scientific Outlook on Development.

(2) An overall social requirement to the CSOEs.

(3) The necessary condition for realising sustainable development of the CSOEs.

(4) The need for the CSOEs to participate in international economic cooperation.

In Article 2, where it addresses the guidelines, requirements and principles, it states that (emphasis added):

(1) Guidelines: CSOEs should take Deng Xiaoping Theory and the Important Thought of Three Represents as the guiding principles, thoroughly apply the Scientific Outlook on Development, adhere to the demands of human-oriented policy and sustainable development strategy from the Central Government of China, enhance their awareness of social responsibility and sustainable development, make overall planning with due consideration of every aspect. They should actively embody their responsibilities and set up good examples for other enterprises in fulfilling CSR so as to promote the construction of a harmonious and well-off society.

(2) Requirements: CSOEs should enhance the awareness of CSR, actively implement CSR, setting example in legal and honest business operation, resource-saving and environment protection. CSOEs should also be the model in building humanoriented and harmonious enterprise and become the backbone of China not only in economy but also in CSR.

(3) Principles: CSOEs should integrate CSR with their own reform and development and regard the implementation of CSR as an important content of setting up modern enterprise system and enhancing their competitiveness. By transforming the pattern of growth and achieving sound and rapid development, they should implement CSR according to the practical situation of the country and the circumstances of themselves, highlight key issues and make out concrete plan, so as to strive for a substantial effect in implementing their CSE. In addition, CSOEs ought to give top priority to ensuring work safety, safeguarding the legal interests of employees, promoting career development of employees. These, as measures to build a harmonious relation between the enterprise and its employees, will also contribute to the China's undergoing programme of building a harmonious society.

Obviously, environmental protection is one of the key interests promoted by the Chinese government, and CSOEs are required to enhance the awareness of CSR (where environmental protection is one of the key issues). It is therefore not surprising to see companies respond extremely positively to environmental issues. The sample reports show a remarkable consistency in reporting environmental information. At the beginning of their environmental reports, companies are eager to show their commitment. A typical example is from the 2011 CSR report of Baosteel (an SOE):

A leader in Chinese iron and steel manufacturing and a provider of environmental-friendly products and services, Baosteel advocates and is dedicated to the green industrial chain. In addition to facilitating comfortable modern life, we are devoted to the mission of environmental protection and environmental burden relief. 
AAAJ

34,9

Baosteel claims that it is not only an advocate of, but is also dedicated to, environmental issues. Through this statement, Baosteel justifies its involvement in environmental issues and thus implicitly identifies itself as a responsible actor. Following this initial statement, the report goes on to list five specific commitments and states that being environmentally friendly is the way towards achieving sustainable development and the way that it can achieve harmonious development. It further declares that having environmentally friendly operations is the principle of its development strategy, workflow and daily operations. The statements impress upon the reader that the company's activities are environmentally friendly by default, as environmentally friendly operations are an intrinsic aspect of its business operations and a prerequisite for business. This is not unique among the sample companies as words such as "actively", "positively", "strengthen", "attach great importance to", "set high priority to", "strive" and "resolutely implement" frequently appear when the companies describe their commitments. This shows how eager the companies are in trying to show that they know what they should do and that they are willing to do so.

According to Bourdieu (1989), to legitimatise their interest as part of their exercise of symbolic power, dominant agents will neutralise their interest as the universal interest ("consensus"). Through manufacturing "consensus", the dominant group is able to produce and inculcate habitus which "encourages the perception of practices that will be positively sanctioned by others as reasonable and best adjusted to the logic of a setting" (Farjaudon and Morales, 2013, p. 158).

The process is similar in the field of Chinese CER. In stating that environmental protection is a basic or inherent feature of the companies' business philosophy, the companies claim they are not just passively responding to demands and that there is no conflict between the companies' business decisions and environmental protection and, more implicitly, that there is no conflict between shareholders and other stakeholders. In this way, companies impose CER as a purely objective exercise removed from operational strategies and as an attempt to prevent criticism of their practices.

Further, through shareholdings in SOEs, the Chinese government can influence not only the decision-making of SOEs, but also that of the wider private sector. As a result of economic liberalisation and SOE reforms in the 1990s, SOEs have largely retreated from most of the downstream sectors (such as product manufacturing and many services including hotel and restaurants), and private enterprises now dominate these sectors. However, SOEs still monopolise the upstream industries (Du and Wang, 2013). The upstream industries provide intermediate goods or services that the downstream sectors need as necessary input for their business operations. This enables the Chinese government to shape the overall market by allocating resources to their favoured industries. Therefore, in order to survive, the private sector is likely to want to adhere to the government's policies when making decisions.

This process is also reflected in their CER. For example, Baosteel, an SOE and an upstream industrial company, stated in its 2011 CSR report that:

Baosteel [... ] drive suppliers to improve their own management and fulfil their social responsibility of energy conservation and environmental protection, [ . . . . In Baosteel's ship carrier selection, ISM/ NSM certificates were required for the carriers or their management vendors. In 2011, all major carriers of Baosteel are with ISM/NSM certificates.

It can be seen that Baosteel gives preference to suppliers that fulfil the green procurement policies. With this process, Baosteel, an SOE, successfully helps the Chinese government to shape the decision-making of the Chinese private sector firms. As discussed previously, dominant groups legitimise their interest as general interest and at the same time disqualify non-dominant groups' interests. In order to accumulate different types of capital, nondominant groups will consciously or unconsciously identify with the interest of the dominant 
group. It is evident that through shareholdings in SOEs, the Chinese government exerts symbolic power over not only SOEs, but also over non-SOEs.

\subsection{The Chinese government's exercise of symbolic power as appointor}

In this section, we argue that key members of the management board of SOEs are appointed and removed by the Chinese government in its exercise of symbolic power. As an agent, SOEs will adhere to its principle's (the Chinese government's) requirements. The language of complying with the government's policies and guidelines in CER is the evidence of this process. It can be seen that the Chinese government's appointment power overlaps with its regulator power and shareholder power. The analysis is elaborated on as follows.

As discussed in Section 4.3, the companies claim that they are proactive practitioners regarding environmental protection. However, the findings show that their arguments for environmental responsibility are based on the representation of their behaviour as a response to the government's demands and expectations. The analysis reveals that the companies explicitly disclose their compliance with laws, regulations and the Chinese government's policies and guidelines under headings such as "Response to the nation's call of green environment", "Response to the nation's call of energy saving and emission reduction" and "company implements nation's energy saving and emission reduction policy". For example, an SOE, COSCO state in their 2011 CSR report:

Guided by the SASAC and the state council's energy saving and emission reduction principle and policies, China COSCO developed and implement the implementation rules and corresponding program.

According to the Law of the People's Republic of China on the State-Owned Assets of Enterprises, Chapter IV, Article 22:

A body performing the contributor's functions shall, according to laws, administrative regulations and enterprise by laws, appoint or remove, or suggest the appointment or removal of the following personnel of a state-invested enterprise:

(1) Appointing and removing the president, vice-presidents, person in charge of finance and other senior managers of a wholly SOE;

(2) Appointing and removing the chairman and vice-chairmen of the board of directors, directors, chairman of the board of supervisors and supervisors of a wholly stateowned company; and

(3) Proposing the director and supervisor candidates to the shareholders' meeting or general assembly of shareholders of a company in which the state has a stake, whether controlling or non-controlling. The directors and supervisors of a stateinvested enterprise who shall be employee representatives shall be elected democratically by employees according to the relevant laws and administrative regulations.

Moreover, the CPC committee is a part of the companies' management system (normally embedded in the human resources department). According to the CPC's agenda Chapter V, Article 33, the SOE's party committee plays a central role in supervising and ensuring the party's and the state's policies and guidelines are fully implemented. The way for a party committee in a company to carry out its role is for the party committee to be involved in the company's major decision-making and for the chairman of the party committee of a company to also be the director of the company. Therefore, appointments within SOEs are an important means for the CPC to exert control (Sheng and Zhao, 2012). The primacy of the party is a core component of Marxist ideology as shown in the way that all CEOs of the major SOEs have a
Chinese
government's
political
ideology 
AAAJ 34,9

"red machine" in their offices that provides an instant (and encrypted) link to the Party's headquarters (McGregor, 2010).

As mentioned in Section 4.1, a new political commitment of building up a "Harmonious Society" was introduced by China's chairman Hu Jintao. This commitment was translated into targets of the Eleventh Five-year Plan (2006-2010) (hereafter referred to as the Plan), which maps strategies for the country's development. These targets required the reduction of energy consumption per unit of GDP by $20 \%$ and reduced sulphur dioxide (SO2) and chemical oxygen demand (COD) emissions by $10 \%$ from 2005 levels by 2010 (Chinese Central Government, 2006). Later, Premier Wen Jiabao announced three new policies: integrating environmental protection and economic decision-making on an equal footing, further decoupling pollutant emissions from economic growth and applying a mix of instruments to resolve environmental problems (Bina, 2010). It is not surprising therefore that SOEs are the ones that most often cite the nation's policy.

In particular, the Plan that maps all the Chinese economic developments and sets the energy-saving and emission reduction targets is commonly referred to. For example, Baosteel's 2010 CSR report which is signed off by their Chairman of the Board of Directors, Mr He Wenbo and President, Mr Ma Guoqiang, both of whom are CPC members and appointed by the State Council of the People's Republic of China, states that:

[t]he State promulgated and promoted policies for contractual energy management as a new energysaving service mechanism, thus clearing away obstacles regarding management system so as to facilitate implementation of contractual energy management system by enterprises. Baosteel Group responded actively, [. . .]Baosteel Co., Ltd [ . . . ] all outperformed the overall goal of energy savings for "action of one thousand enterprises" signed with the National Development and Reform Commission respectively. Wherein, the aggregate energy savings of Baosteel Co., Ltd. [. . .] exceeded the quota by $21 \%$ and the energy savings of Xinjiang Bayi Iron and Steel exceeded the quota by $99 \%$. The SO2 and COD of Baosteel declined by $63 \%$ and $86 \%$ respectively in the "Eleventh Five-year Planning" period.

In line with the notion of symbolic power, reporting against the assigned targets indicates that the CSR report is more likely to be aimed at reporting to the government, especially for SOEs, as they are required to be leaders in environmental protection practices. Notably, key members of the management board of SOEs are appointed and removed by the Chinese government. As agents respond to these principles, it is not surprising that the SOEs have a common goal, in terms of environmental protection, with the Chinese government, and would like to show compliance with the government's policies.

Interestingly, even for companies that are non-SOEs, compliance with national policy is the main theme that can be found in their reporting. For example, the 2011 CSR report of Minsheng bank, which is signed off by its CEO, Mr Dong Wenbiao, who also is a CPC member, states that

[ $t$ the bank has always believed that it is a general trend for the banks to implement the national green credit policy and develop sustainable finance, [...] In 2011, the bank actively responded to the national policy, and strictly controlled loan size and adjusted the credit structure in high energyconsuming and high polluting industries, $[\ldots]$.

The legitimising strategy here is clear. The company first argues that complying with the national policy is the trend, thereby establishing common ground with the reader that there is no conflict between the national policy and the company's economic goals. After creating an image of itself as a responsible business, it then describes how firmly it implements the national policy. One possible reason the companies are keen on showing their endeavours to respond to the Chinese government's guidelines and policies is how the ideology has been accepted by the whole country. This is reinforced by key executives and board members who 
are appointed by the SASAC and who are almost always CPC members. They are keen to show loyalty and gain political mileage with their appointors. As mentioned previously, environmental protection has been developed as the general consensus and has been prioritised in the nation's policy. By referring to the government's policies or/and guidelines, the company gradually identifies with the nation's interest and therefore legitimises their behaviour and thus gains approval from society.

On examining non-SOEs, it is interesting that although the SASAC does not have controlling interest in these companies, there is still a strong link between the Chinese government and these companies. As shown in Table 2, all non-SOEs have an embedded CPC committee, their director is at the same time the chairman of the party committee, and most of the senior members of the management board are also members of the $\mathrm{CPC}$ committee. In addition, in these companies' management boards, a number of members are currently, or were previously, government officers. Thus, even non-SOEs are deeply involved in the Chinese government's bureaucratic system, which enables the Chinese government to exercise symbolic power over their decision-making. For example, FuYao Glass Industry was previously a local SOE, which was privatised in 2007. Although the company is now fully private, the director of the company is a member of the Chinese People's Political Consultative Conference (CPPCC) of the Fujian Province, as well as a research fellow of the Fujian government's Economic Development Centre. From our sample of non-SOE firms, all the firms' CEOs/MDs were also CPC members. It can be seen that the links between the government and the non-SOEs are strong, and in order to gain support from the Chinese government, the non-SOEs would likely be involved in the bureaucratic system.

Compliance with the Chinese government can also be seen in the language companies use in interpreting their environmental activities. It is argued that Chinese communist leaders are good at using campaign slogans to convey the Party's policies and political ideologies. Fourword (four Chinese characters) mottos are the main substance of their political ideologies, and these are displayed as slogans on billboards or in public places (Yee, 2009). Through these mechanisms, it ensures the proliferation of its interest, and these interests (which are translated into government policies) become ingrained into the everyday lives of the Chinese people (Yee, 2009). As discussed earlier, "harmonious society (和谐社会)" and “scientific development (科学发展)" have become the new agenda-framing meta-discourse since the 2000s (Zhang, 2012). These Chinese propaganda slogans have been incorporated into the habitus that has been accepted in the discourse and consequently have influenced the behaviour among Chinese firms with respect to CER. "harmonious society" and "scientific development" appear frequently in the Chinese CER examined. For example, Minsheng Bank's 2009 CSR report states that:

A good ecological environment is the foundation of social and economic sustainable development, as well as the important content of scientific development and harmony society.

Similar political slogans can also be seen in China COSCO's 2008 CSR report:

[I]t has realised the coordinated and sustainable development of enterprise value, humanistic environment and natural environment and made contributions for the building of a harmonious socialist society.

Also, in its 2010 CSR report:

Based on the strategic plan of the "Eleventh Five-Year Plan" and in line with its scientific development, the Company exerted great efforts in maintaining the harmony among corporate development, the environment and the community.

It is clear that Chinese companies adopt the language of political propaganda as a legitimacy device that helps them to gain prestige. Both SOEs and non-SOEs show how dedicated they are to these policies and that they devote themselves to environmental protection as

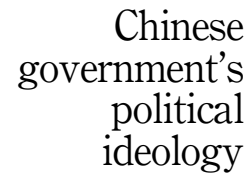

19 
AAAJ

34,9

promoted by the government. As mentioned earlier, the directors of the firms are either directly appointed by the Chinese government or have a strong relationship (such as being CPC members and/or members of the National Committee of CPPCC) with the Chinese government. To accumulate their individual political capital, the directors are willing to be accountable to the Chinese government. Using propaganda slogans in their reporting is perceived to be an effective way to show their compliance; therefore, political slogans appear frequently in the Chinese CER examined. Evidently, through appointing and controlling senior leadership in both SOEs and non-SOEs, the Chinese government's political ideology has been successfully internalised into the cognition of the companies such that compliance with the government's policies has become something taken for granted. The Chinese government has thus successfully inculcated environmental protection as a habitus within Chinese companies, and this ultimately influences their decision to engage in CER.

\subsection{From symbolic capital to economic capital}

In line with this, the practice of symbolic power and control in China has changed over time, and there is evidence of newer, more sophisticated strategies for exercising control in this aspect, particularly through the control of economic capital, by the government. The results of this study indicate that the Chinese government impacts CER broadly through its ability to influence strategic change through economic planning and restructuring and its ability to direct resources to sectors and firms that the party deems "important". Specifically, government grants and governmental financial institutes are used to help the Chinese government to achieve its political goal of being green.

According to the Plan, about 1.35 trillion RMB, which accounts for $1.35 \%$ of each year's GDP, should be invested in environmental protection programmes. It also lists six areas as the investment focus and among them, water pollution treatment and air pollution (mainly sulphur dioxide) treatment are the priorities. Therefore, to attract government grants and tax benefits, the treatment of water pollution and air pollution is a major theme of Chinese CER. Table 2 shows that six out of seven companies received grants from the government, and two of the six explicitly show that the grants were environment-related. In order to attract this funding, it is not surprising that the companies work as an agent of the government, that is to say, the companies' governing strategies will tend to satisfy the Chinese government's policies first.

In addition, these types of policies significantly affect the businesses' survival. This is especially so for non-SOEs that need to express their efforts in changing the way they operate their business and focus on new technology or equipment that has been invested in or developed or on new green products that have been produced to avoid being negatively targeted by the government. This can also explain why environmental protection is articulated as energy saving and emission reduction as noted earlier.

Moreover, in addition to the government, banks are another important financial resource for environmental protection. In China, all banks, including commercial banks, are supervised by the government; banks play an important role in directing money to industries or even companies that are favoured by the government. In December 2007, the State EPA of China, together with the People's Bank of China and China Banking Regulatory Commission, issued the Opinions of Implementing Environmental Protection Policies and Regulations and Preventing Credit Risks. It requires credit organisations to follow the state's industry policy and direct money to government-promoted industries. In particular, commercial banks are to view controlling the amount of credit provided to polluting companies as an important part of implementing their social responsibility. It also emphasised that commercial banks should restrict the amount of credit provided to polluting companies, according to the information provided by the different levels of the EPA. 
Symbolic capital is "the particular form that one or another of these species takes when it is grasped through categories of perception that recognize its specific logic" (Bourdieu and Nice, 1990, p. 119). As mentioned in Section 2, capitals can be transformed between forms. In this case, the capital of honour and prestige of environmental protection became the symbolic capital in the field of Chinese CER. In order to maintain and improve their social position, the Chinese companies seek to accumulate symbolic capital through disclosing environmental information. In turn, the instilling disposition and attitude can be translated into economic opportunities. Accumulating symbolic capital ultimately facilitates companies to accumulate economic capital. As discussed earlier, the Chinese government controls significant sources of economic capital that is essential for the survival and performance of companies. As a result, many of these Chinese companies have chosen to disclose information that favours the Chinese government to accumulate economic capital.

Overall, in order to be picked by the Chinese government as an industry "winner", Chinese companies view the state as their most important stakeholder when producing CER and that CER is directly a response to the government's policies. However, this is not as straightforward as it may first appear, as China is entering a phase of development where Western influences may begin to have a moderating effect on the strength of the ideology. This is considered in the next section.

\subsection{The struggle in the construction of CER in China}

According to an interview with Bourdieu (Honneth et al., 1986), there is always conflict between groups with different interest, and a new field or a new social structure in the field is the result of struggles over classification and capital in a specific historical point. This struggle can also be seen in the construction of CER in China. While there is evidence that the Chinese government's influence on Chinese CER is strong, some new features have appeared in some advanced companies' reports in more recent years. There is a trend that indicates that the external influences on CER, especially from developed Western economies, is becoming more important. From 2010, the companies with the highest level of disclosure in all four groups examined have started to emphasise their environmental practices in the global context. They disclosed their compliance with global guidelines and standards as well as with Chinese policies. An example of this is China COSCO's 2011 CSR report:

It joined the UN Global Compact Project Team on Climate Change, partnered with companies in shipping industry on researches of technological applications, including carbon footprint calculation of supply chain and tracing of implementation situations of green passport.

They also disclosed their cooperation with international organisations and the international awards they have received. For example, Baosteel reported in 2010 that they beat other wellknown companies to win a project in the United Nations Environment Programme.

The companies have also started to evolve in terms of their standard setting processes. Baosteel reported that they are involved in the development of the Greenhouse Gas Protocol developed by the World Resources Institute and the World Business Council for Sustainable Development. China COSCO reported that they cooperated with the World Business Council for Sustainable Development to develop the standards of sustainable development for the shipping industry. These global influences bring a more sophisticated sustainability philosophy to the companies whereby protecting the environment is not only to fulfil the Chinese government's requirements, but they also need to embed it in their overall risk management systems. As the Industrial Bank states in their 2011 CSR report:

The adoption of Equator Principles was as good as a revolution, it completely revolutionized the values of the bank and to promote the transformation of the business. [...] adoption of Equator 
AAAJ 34,9

Principles will also be an inevitable trend for commercial banks committed to the sustainable development in the future.

This may be a signal that to operate as a leading company in the global economy, there is a need to adopt such internationally driven policies, on top of what the government is dictating at home. In order to stand out from their competitors, they must accept environmental protection as part of their business.

Unsurprisingly, the dual-listed companies are among those adopting these more sophisticated approaches earlier. As they are listed on overseas stock exchanges, they face more pressure from foreign stakeholders who are more concerned about environmental issues, and they face more rigorous regulations for publishing transparent information about environmental issues. In addition, companies that are not listed on overseas stock exchanges, but who have foreign shareholders, are also influenced by the West. For example, the Industrial Bank is not listed overseas; however, the Hong Kong-based bank, Hang Seng Bank holds $12.8 \%$ of the shares of the Industrial Bank. As a result, compliance with the Equator Principles becomes a very important part of its CER. There is also a trend in some of the companies that, even though they are not dual-listed, if their directors, supervisors or senior members of the management board have an overseas degree or overseas working experience, the companies tend to have better CER. For example, the Industry Bank is a non-dual-listed company, but onethird of its management board members have overseas working experience. Consequently, they provide more comprehensive CER. Moreover, if the companies have overseas business operations, they tend to disclose more environmental information. For example, Baosteel is not a dual-listed company, but it has overseas subsidiaries in America, Japan, Germany, Singapore and Hong Kong and therefore provides more advanced CER. Thus, it can be seen that Western influence is leading to the emergence of another dominant group that is mediating the symbolic power of the State. Whether and how this change may influence the habitus would be an interesting area that needs further research.

\section{Conclusion}

The objective of this study is to better understand whether and how the Chinese government's political ideology influences the companies' decision-making process, in terms of CER as informed by Bourdieu's conceptualisation of symbolic power. The analysis shows that through building consensus among Chinese companies, the Chinese government's political ideology is naturalised and becomes the habitus embedded in the companies. Thus, disclosing environmental information that adheres to the Chinese government's political ideology is considered as patriotism that can raise the companies' image and facilitate them to be picked by the government as an industry winner and therefore have more opportunity to obtain the crucial resources they need. The findings show that Chinese CER is a product of symbolic power. The process of turning political ideology into naturalised habitus is where the Chinese government's symbolic power is revealed.

In response to Malsch et al.'s (2011, p. 219) call for more attention to be paid to habitus when relying on Bourdieu's ideas in carrying out empirical research (in particular, the notion of symbolic power), our study examines the process of how the Chinese government turns its political ideology into consensus among companies. Our results show that the Chinese government uses newer, more sophisticated forms of ideological control, especially through the political-economic control of factor resources such as capital (e.g. government grants and access to governmental financial institutions) to enforce the guiding ideology, and therefore the Chinese government successfully builds habitus among companies. In particular, in a sophisticated application of symbolic power, the leader's signature ideology has been integrated into the discursive structures of the field of CER. Therefore, it can be seen that Chinese CER is not ideologically neutral. The Chinese government's ideology strongly shapes 
the values that underpin Chinese CER. In contrast to the previous research that has largely focussed on the influence of the Chinese government on SOEs, this study provides new evidence that the new flows of accounting information modify companies' perception and alter their disposition towards the additional reporting requirements in the field. Therefore, CER gives the traditionally dominated companies, non-SOEs, an opportunity to accumulate the symbolic capital to become more dominant and successfully transfer symbolic capital into economic capital. This study contributes to the critical accounting literature by examining the discourse on political ideology within CERs and highlighting its importance in the Chinese government's exercise of symbolic power. According to Bourdieu (1991, p. 45), to gain/maintain the dominant position in the social space, agents "tacitly accept the official definition of the official language of a political unit" and therefore tend to "use the same system of linguistic signs". Through exploring the use of the same system of linguistic signs, we show that CER in China is more a symbolic product to gain/maintain the dominant position rather than a dialogic approach to engage various stakeholders.

The aforementioned findings have implications for practice and policy. While our research only looks at CER as opposed to environmental performance or impact, we find that governments can have a dramatic and rapid impact on changing private sector views on the importance of environmentally sustainable actions, especially in the context of state capitalism. It reinforces findings by Zhao (2012) and Situ et al. (2018) that CSR/CER in China is a highly politically embedded phenomenon. Combined with the growing influence of overseas practices, this will hopefully see China catching up in this aspect, as it has already done so in other aspects of economic growth and scientific endeavours, to reach similar standards of developed economies. On the other hand, in this study, the discourse of CER of sample companies is examined across several inter-related social contexts. Through the discourse, the companies analysed clearly deliver a message that sustainable development is a trend; that they are a responsible business and stand at the leading edge of a new approach to development. However, it is reported that in 2013, only three major Chinese cities met the government's own standards for urban air quality. In total, $16 \%$ of China's total land area and $19 \%$ of its agricultural land are polluted (Larson, 2014). It appears that the overall condition of China's environment has not improved. The inconsistency between the environmental reality and CER suggests that CER in China is a legitimacy tool aimed at one major stakeholder rather than a tool for accountability or transparency. Therefore, the emergence of global influence that may mediate the government's power may encourage companies to put their words into practice.

The results also indicate areas in need of further investigation. First, as discussed earlier, there is some evidence that the impact of the West has become more noticeable in recent years. It is promising to see that Western influence brings a more advanced and sophisticated concept of corporate responsibility to Chinese companies. Some of these more advanced companies realise that protecting the environment is not just about responding to the government's policy, but more importantly, it is a part of modern business. The prevailing political ideology is thus mitigated by the changing economic circumstances. To operate within the competitive global environment, companies must provide comprehensive CER. This is very preliminary, and it may be a new source of a different type of symbolic power, and so it is an important area for examination in the future as China's economy continues to develop. Second, Bourdieu's conceptualisation of symbolic power addressed issues beyond the superficial exercise of power, an important aspect of Lukes' (1974) three-dimensional classification of power. According to Lukes (1974), the concept of power is "ineradicably evaluative" and "essentially contested" (p. 9). In terms of Lukes' (1974) three-dimensional concept of power, as we have mainly studied CER reports and Chinese government documents, our study remains predominantly in the first dimension which involves direct, observable exercises of power (e.g. CCP controlling issues such as grants and incentives).
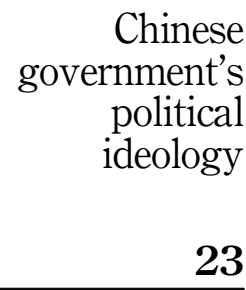
AAAJ 34,9

\section{4}

We have pointed to some evidence of more indirect exercises of power through the exercise of political ideology. However, there may be other aspects of skewed power relationships that may be unobservable and unconscious, as proposed in Lukes' (1974) third dimension, and which is highly likely, given the system of authoritarian capitalism, as shown in research in other state capitalist countries (Seet, 2009). Lukes' (1974) view focusses on latent conflict, inaction rather than observable action and both conscious and unconscious exercises of power, and further research will need to study these unobservable exercises of power between the government (both central, provincial and local) and the companies (both SOEs and non-SOEs) in the contentious issues surrounding the tension between economic and environmental sustainability.

\section{Notes}

1. Hu Jintao is the president of the People's Republic from 2003 to 2013. He held the offices of General Secretary of the Communist Party from 2002 to 2012.

2. Guidelines on Environmental Information Disclosure by Companies Listed on the Shanghai Stock Exchange

\section{References}

Arayssi, M., Jizi, M. and Tabaja Hala, H. (2020), "The impact of board composition on the level of ESG disclosures in GCC countries", Sustainability Accounting, Management and Policy Journal, Vol. 11 No. 1, pp. 137-161.

Bina, O. (2010), "Environmental governance in China: weakness and potential from an environmental policy integration perspective", China Review, Vol. 10 No. 1, pp. 207-240.

Bourdieu, P. (1989), "Social space and symbolic power", Sociological Theory, Vol. 7 No. 1, pp. 14-25.

Bourdieu, P. (1991), Language and Symbolic Power, Harvard University Press, Italy.

Bourdieu, P. (2015), On the State: Lectures at the College de France, 1989-1992, United Kingdom, Polity Press, Oxford.

Bourdieu, P. and Nice, R. (1990), The Logic of Practice, Stanford University Press.

Bourdieu, P. and Wacquant, L.J.D. (1993), "From ruling class to field of power: an interview with pierre Bourdieu on La noblesse d'État", Theory, Culture and Society, Vol. 10 No. 3, pp. 19-44.

Bremmer, I. (2010), "The end of the free market: who wins the war between states and corporations", European View, Vol. 9 No. 2, pp. 249-252.

Brown, J. and Dillard, J. (2014), "Integrated reporting: on the need for broadening out and opening up", Accounting, Auditing and Accountability Journal, Vol. 27 No. 7.

Brown, J. and Tregidga, H. (2017), "Re-politicizing social and environmental accounting through Rancière: on the value of dissensus", Accounting, Organizations and Society, Vol. 61, pp. 1-21.

Celerier, L. and Cuenca Botey, L.E. (2015), "Participatory budgeting at a community level in Porto Alegre: a bourdieusian interpretation", Accounting Auditing and Accountability, Vol. 28 No. 5, pp. 739-772.

China Daily (2007). "New law to promote energy conservation", available at: http://www.chinadaily.com. cn/china/2007-10/24/content_6204400.htm (accessed 20 December 2019).

Chinese Central Government (2006), “The 11th Five-year Plans of People's Republic of China (中华人 民共和国国民经济和社会发展第十一个五年规划纲要)”, available at: http://news.xinhuanet. com/misc/2006-03/16/content_4309517_1.htm (accessed 20 August 2011).

Cooper, C. and Coulson, A.B. (2014), “Accounting activism and Bourdieu's 'collective intellectual' reflections on the ICL case", Critical Perspectives on Accounting, Vol. 25 No. 3, pp. 237-254. 
Cronin, C. (1996), "Bourdieu and Foucault on power and modernity", Philosophy and Social Criticism, Vol. 22 No. 6, pp. 55-85.

Deegan, C. (2009), "Unregulated corporate reporting decisions: systems-oriented theories", Financial Accounting Theory, Mcgraw-Hill, Sydney, pp. 318-377.

Dong, S., Burritt, R. and Qian, W. (2014), "Salient stakeholders in corporate social responsibility reporting by Chinese mining and minerals companies", Journal of Cleaner Production, Vol. 84 No. 1, pp. 59-69.

Du, J. and Wang, Y. (2013), "Reforming SOEs under China's state capitalism", in Zhang, J. (Ed.), Unfinished Reforms in the Chinese Economy, World Scientific Publishing, Singapore, pp. 1-38.

Dumay, J. and Guthrie, J. (2019), "Reflections on interdisciplinary critical intellectual capital accounting research: multidisciplinary propositions for a new future”, Accounting, Auditing and Accountability Journal, Vol. 32 No. 8, pp. 2282-2306.

Egan, M. and Tweedie, D. (2018), “A 'green' accountant is difficult to find: can accountants contribute to sustainability management initiatives?", Accounting, Auditing and Accountability Journal, Vol. 31 No. 6, pp. 1749-1773.

Everett, J. (2003), "The politics of comprehensive auditing in fields of high outcome and cause uncertainty", Critical Perspectives on Accounting, Vol. 14 Nos 1-2, pp. 77-104.

Ezzamel, M., Xiao, J.Z. and Pan, A. (2007), "Political ideology and accounting regulation in China", Accounting, Organizations and Society, Vol. 32 No. 7, pp. 669-700.

Farjaudon, A.L. and Morales, J. (2013), "In search of consensus: the role of accounting in the definition and reproduction of dominant interests", Critical Perspectives on Accounting, Vol. 24 No. 2, pp. 154-171.

Ferguson, J., Sales de Aguiar, T.R. and Fearfull, A. (2016), "Corporate response to climate change: language, power and symbolic construction", Accounting, Auditing and Accountability Journal, Vol. 29 No. 2, pp. 278-304.

Finau, G. (2020), "Imagining the future of social and environmental accounting research for pacific small island developing states", Social and Environmental Accountability Journal: Social and Environmental Accountability 2020 and Beyond, Vol. 40 No. 1, pp. 42-52.

Fukofuka, P. and Jacobs, K. (2018), "Accounting as capital and doxa: exploring power and resistance in World Bank projects in Tonga", Accounting, Auditing and Accountability Journal, Vol. 31 No. 2, pp. 608-625.

Gao, Y. (2011), "CSR in an emerging country: a content analysis of CSR reports of listed companies", Baltic Journal of Management, Vol. 6 No. 2, pp. 263-291.

Global Times (2012), “China's commitments to fight climate change”, available at: http://www.china. org.cn/environment/doha_climate_talks/2012-11/28/content_27254355.htm (accessed 15 December 2019).

Glynos, J., Howarth, D., Norval, A.J. and Speed, E. (2009), Discourse Analysis: Varieties and Methods, ESRC National Centre for Research Methods NCRM/014 2009 [cited 10/Aug 2014], available at: http://eprints.ncrm.ac.uk/796/.

Hafenbrädl, S. and Waeger, D. (2017), "Ideology and the micro-foundations of CSR: why executives believe in the business case for CSR and how this affects their CSR engagements", Academy of Management Journal, Vol. 60 No. 4, pp. 1582-1606.

Hardy, C. and Phillips, N. (1999), "No joking matter: discursive struggle in the Canadian refugee system”, Organization Studies, Vol. 20, pp. 1-24.

Honneth, A., Kocyba, H. and Schwibs, B. (1986), "The struggle for symbolic order an interview with pierre Bourdieu", Theory, Culture and Society, Vol. 3 No. 3, pp. 35-51.

Hummel, P. and Hörisch, J. (2020), "The hidden power of language: how 'value creation accounting' influences decisions on expenditures, cost reductions and staff costs", Sustainability Accounting, Management and Policy Journal, Vol. 11 No. 1, pp. 187-206. 
AAAJ 34,9

Kamala, R. and Komori, N. (2018), "Diagnosing translation gap: the politics of translation and the hidden contradiction in interdisciplinary accounting research", Accounting, Auditing and Accountability Journal, Vol. 31 No. 7, pp. 1874-1903, doi: 10.1108/AAAJ-08-2017-3067.

Killian, S. and O'Regan, P. (2016), "Social accounting and the co-creation of corporate legitimacy", Accounting, Organizations and Society, Vol. 50, pp. 1-12.

Landry, P.F. (2008), Decentralized Authoritarianism in China, Cambridge University Press, New York, NY.

Larson, C. (2014), China's Environment Goes from Bad to Worse, Bloomberg Business 2014 [cited 28/ Apr 2015], available at: http://www.bloomberg.com/bw/articles/2014-06-10/air-water-soil-chinasenvironment-gets-worse.

Lauwo, S.G., Otusanya, O.J. and Bakre, O. (2016), "Corporate social responsibility reporting in the mining sector of Tanzania", Accounting, Auditing and Accountability Journal, Vol. 29 No. 6, pp. 1038-1074.

Li, C. (2011), “China's midterm jockeying: gearing up for 2012 (Part 4: top leaders of major state-owned enterprises)", China Leadership Monitor, Vol. 34 No. 4, p. 105.

Li, X., Liu, X. and Wang, Y. (2012), A Model of China's State Capitalism, available at: https://ssrn.com/ abstract=2061521 or http://dx.doi.org/10.2139/ssrn.2061521.

Lieber, A. (2013), "The Chinese ideology: reconciling the politics with the economics of contemporary reform”, Journal of Chinese Political Science, Vol. 18 No. 4, pp. 335-353.

Lukes, S.M. (1974), Power, a Radical View, Macmillan, London.

Magness, V. (2006), "Strategic posture, financial performance and environmental disclosure", Accounting, Auditing and Accountability Journal, Vol. 19 No. 4, pp. 540-563.

Malsch, B., Gendron, Y. and Grazzini, F. (2011), "Investigating interdisciplinary translations: the influence of Pierre Bourdieu on accounting literature", Accounting, Auditing and Accountability Journal, Vol. 24 No. 2, pp. 194-228.

Marinellin, M. (2012), "Disembodied words: the ritualisitc quality of political discourse in the era of Jiang Zemin", in Chilton, P., Tian, H. and Wodak, R. (Eds), Discourse and Socio-political Transformations in Contemporary China, John Benjamins Publishing.

McGregor, J. (2010), China's Drive for 'Indigenous Innovation' - A Web of Industrial Policies, U.S Chamber of Commerce.

McNally, C.A., Lüthje, B. and Brink, T.T. (2013), "Rebalancing China's emergent capitalism: state power", Economic Liberalization and Social Upgrading Journal of Current Chinese Affairs, Vol. 32 No. 4, pp. 3-16.

McPhail, K., Paisey, C. and Paisey, N.J. (2010), "Class, social deprivation and accounting education in Scottish schools: implications for the reproduction of the accounting profession and practice", Critical Perspectives on Accounting, Vol. 21 No. 1, pp. 31-50.

Milne, M.J., Walton, S. and Tregidga, H. (2009), "Words not actions! the ideological role of sustainable development reporting", Accounting, Auditing and Accountability Journal, Vol. 22 No. 8, pp. 1211-1257.

Nelson, R. (2008), “Water pollution in China: how can business influence for good?”, Asian Business and Management, Vol. 7, pp. 489-509.

Parker, L.D. and Northcott, D. (2016), "Qualitative generalising in accounting research: concepts and strategies", Accounting, Auditing and Accountability Journal, Vol. 29 No. 6, pp. 1100-1131.

Pew Charitable Trust (2010), Who's Winning the Clean Energy Race? Growth, Competition and Opportunity in the World's Largest Economies, Pew Charitable Trust, Washington D.C.

Qian, Y. and Tian, H. (2014), "A decade of change in China: a corpus-based discourse analysis of ten government work reports", in Cao, Q., Tian, H. and Chilton, P. (Eds), Discourse, Politics and Media in Contemporary China, John Benjamins Publishing, pp. 77-95.

Quinche-Martín, F.L. and Cabrera-Narváez, A. (2020), "Exploring the potential links between social and environmental accounting and political ecology", Social and Environmental Accountability Journal: Social and Environmental Accountability 2020 and beyond, Vol. 40 No. 1, pp. 53-74. 
Seet, P.S. (2009), "Power paradoxes in national innovation systems-an exploratory study among Singapore's technocrats and technopreneurs", International Journal of Foresight and Innovation Policy, Vol. 5 No. 4, pp. 260-276.

Semeen, H. and Islam, M.A. (2020), "Social impact disclosure and symbolic power: evidence from UK fair trade organizations", Critical Perspectives on Accounting, p. 102182.

Sheng, H. and Zhao, N. (2012), China's State-Owned Enterprises: Performance and Reform, World Scientific, Singapore.

Shenkin, M. and Coulson, A.B. (2007), "Accountability through activism: learning from Bourdieu", Accounting, Auditing and Accountability Journal, Vol. 20 No. 2, pp. 297-317.

Situ, H. and Tilt, C.A. (2012), "Chinese government as a determinant of corporate environmental reporting: a study of large Chinese listed companies", Journal Asia-Pacific Centre for Environmental Accountability, Vol. 18 No. 4, pp. 251-286.

Situ, H. and Tilt, C. (2018), "Mandatory? Voluntary? A discussion of corporate environmental disclosure requirements in China", Social and Environmental Accountability Journal, Vol. 38 No. 2, pp. 131-144.

Situ, H., Tilt, C.A., Pi-Shen, S. and Max, S. (2013), "Understanding the impact of Chinese government and other stakeholders on corporate environmental reporting in China", 7th Asia Pacific Interdisciplinary Research in Accounting Conference (APIRA), Kobe, Japan.

Situ, H., Tilt, C. and Seet, P.S. (2015), "Corporate environmental reporting (CER) in China: a stakeholder perspective", Paper read at Australasian Centre on Social and Environmental Accounting Research Conference (A-CSEAR), Sydney.

Situ, H., Tilt, C.A. and Seet, P.-S. (2018), "The influence of the government on corporate environmental reporting in China: an authoritarian capitalism perspective", Business and Society. doi: 10.1177/ 0007650318789694.

Stringfellow, L., McMeeking, K. and Maclean, M. (2015), "From four to zero? The social mechanisms of symbolic domination in the UK accounting field", Critical Perspectives on Accounting, Vol. 27, pp. 86-100.

Swartz, D.L. (2007), "Recasting power in its third dimension", Theory and Society, Vol. 36 No. 1, pp. 103-109.

Sylvia, E.G.S., Prihatiningtias, Y.W. and Roekhuddin (2018), "Public interest and accrual accounting: are they aligned?", Journal of Accounting and Organizational Change, Vol. 14 No. 4, pp. 366-380.

Tadros, H. and Magnan, M. (2019), "How does environmental performance map into environmental disclosure? A look at underlying economic incentives and legitimacy aims", Sustainability Accounting, Management and Policy Journal, Vol. 10 No. 1, pp. 62-96.

The Economist (2012), "State capitalism”, The Economist, January, pp. 1-14.

Tilling, M.V. and Tilt, C.A. (2010), "The edge of legitimacy: voluntary social and environmental reporting in Rothmans' 1956-1999 annual reports", Accounting, Auditing and Accountability Journal, Vol. 23 No. 1, pp. 55-81.

Tilt, C.A. (2018), "Making social and environmental accounting research relevant in developing countries: a matter of context?", Social and Environmental Accountability Journal, Vol. 38 No. 2, pp. 145-150.

Tregidga, H. and Milne, M.J. (2006), "From sustainable management to sustainable development: a longitudinal analysis of a leading New Zealand environmental reporter", Business Strategy and the Environment, Vol. 15 No. 4, pp. 219-241.

van den Burg, S.W.K. (2008), "Environmental information disclosure in China", International Sociological Association, Barcelona, pp. 1-16.

Van Dijk, T.A. (2009), "Critical discourse analysis: a sociocognitive approach", Methods of Critical Discourse Analysis, 2nd ed., SAGE Publication, London, pp. 62-86.

Wodak, R. and Meyer, M. (2009), Methods of Critical Discourse Analysis, 2nd ed., SAGE Publication, London. 


\section{AAAJ}

34,9

28
World Bank (2010), World Development Indicators (WDI) Database 2008, [cited 07/Apr 2010], available at: http://web.worldbank.org/WBSITE/EXTERNAL/DATASTATISTICS/0contentMDK: 20535285 menuPK:1192694 pagePK:64133150 piPK:64133175 theSitePK:239419,00.html.

World Bank and State Environmental Protection Administration (2011), Cost of Pollution in China: Economic Estimates of Physical Damage 2007, [cited 09/September 2011], available at: http:// www.worldbank.org/research/2007/02/7503894/cost-pollution-china-economic-estimatesphysical-damages.

$\mathrm{Xu}, \mathrm{L}$., Zhang, E. and Cortese, C. (2018), "Exploring the role of accounting in the people's commune of China between 1958 and 1966", Accounting, Auditing and Accountability Journal, Vol. 32 No. 1, pp. 194-223.

Xue, L., Simonis, U.E. and Dudek, D.J. (2007) "Environmental governance for China: major recommendations of a task force”, Environmental Politics, Vol. 16 No. 4, pp. 669-676, doi: 10. 1080/09644010701419196.

Yee, H. (2009), "The re-emergence of the public accounting profession in China: a hegemonic analysis", Critical Perspectives on Accounting, Vol. 20 No. 1, pp. 71-92.

Zhang, Q. (2012), "The discursive construction of the social stratification order in reforming China", in Chilton, P., Tian, H. and Wodak, R. (Eds), Discourse and Socio-Political Transformations in Contemporary China, John Benjamins Publishing Co., Amesterdam, pp. 19-37.

Zhang, B., Bi, J., Yuan, Z., Ge, J., Liu, B. and Bu, M. (2007), "Why do firms engage in environmental management? An empirical study in China", Journal of Cleaner Production, Vol. 16 No. 10, pp. 1036-1045.

Zhao, M. (2012), "CSR-based political legitimacy strategy: managing the state by doing good in China and Russia", Journal of Business Ethics, Vol. 111 No. 4, pp. 439-460.

Zheng, Y. (2010), China Model: Experience and Dilemma (中国模式:经验与困局), Zhengzhou People Publishing House, (In Chinese).

\section{Corresponding author}

Hui Situ can be contacted at: hui.situ@rmit.edu.au

For instructions on how to order reprints of this article, please visit our website:

www.emeraldgrouppublishing.com/licensing/reprints.htm

Or contact us for further details: permissions@emeraldinsight.com 